\title{
Effect of Protective Forest Strip on the Crop Productivity in the Central Fore-Caucasus
}

\author{
Alexander N. Esaulko, Ludmila V. Trubacheva, Olga I. Vlasova, \\ Irina A. Volters and Vera M. Perederieva
}

Stavropol State Agrarian University, 12, Zootehnichesky Pereulok, Stavropol 355017, Russia.

http://dx.doi.org/10.13005/bbra/2015

(Received: 11 February 2016; accepted: 15 March 2015)

\begin{abstract}
At present all the necessary information has been accumulated on current topic, and our findings confirm once again the opinions of many scientists about the positive effect of protective forest strips on the wind-resistance, snow accumulation, humidity dynamics, and infestation of crops. The article presents research data concerning the ameliorative role of protective forest strips on the crops productivity evidence from winter wheat. Remoteness from a protective forest strip substantially affected the accumulation of productive moisture by the time of winter wheat sowing. In this regard, we determined the content of productive moisture in the soil for all experimental plots. Besides, soil moisture formation strongly depended on snow accumulation. Thus, moving away from the protective forest strip resulted in decrease of the snow cover depth. At a distance of 10-20H from the protective forest strip, the snow cover depth was $25-30 \mathrm{~cm}$ decreasing to 5-10 cm with further increase in the distance. The overall influencing distance of protective forest strips varies from 0 to 30í. The same trend was maintained with regard to the formation of moisture content. Impact on weediness was manifested in such a way that the smallest amount of weeds was observed at a distance of $0-10 \mathrm{H}$. When moving away from the protective forest strip, the amount of weeds grew, as well as species composition, and further $(30-40 \mathrm{H})$ the amount of weeds per square meter decreased. The maximum wheat yield $(3.86 \mathrm{t} / \mathrm{ha})$ was obtained at a distance of $10-20 \mathrm{H}$ from the protective forest strip.
\end{abstract}

Key words: protective forest strip, consumptive water use, humidity conditions, infestation, wind erosion.

Central Fore-Caucasus is characterized by a large diversity of natural-climatic conditions, soil covering, landscapes, and rather high bioclimatic potential for the crops cultivation ${ }^{1}$. The landscapes of the Central Fore-Caucasus are characterized by typical forest-steppe with chernozems and gray forest soils, steppe and semidesert areas with chernozems, chestnut soils, saline soils and sand spots, subalpine and alpine meadows of the Greater Caucasus with mountainmeadow soils. At the present time, a wealth of research information about microbial activity at

\footnotetext{
* To whom all correspondence should be addressed.
}

the influence of soil fertility factors has been accumulated ${ }^{2}$. Almost all researchers note a steady tendency in deterioration of agrochemical, agrophysical, and biological properties of soil. For the solution of ecological problems on preservation of agricultural fields against adverse impact of water and wind erosion it is important to determine the effect of protective forest strips on the yield of field crops.

Protective forest plantations on agricultural lands at their correct placement are active regulators of biological and ecological balance in degraded landscapes. This essential importance of planted forests has not been fully studied: there is need for quantitative assessment of water regulation, soil conservation, agronomical, and bioenergetic effectiveness of protective forest 
strips as an essential element of anti-erosion complex ${ }^{3}$.

Some scientists believe that microbiological activity of the soil under winter wheat increases while getting closer to protective forest strip. The studies revealed that forest shelter belts in combination with soil-protective technologies contribute to winter wheat productivity by $10-15 \%$.

Other researchers define the main role of protective forest strips in the physical protection of crops against wind and, as a consequence, reduction of moisture evaporation.

\section{Methodology}

The research was conducted in an arid zone with hydrothermal coefficient of $0.7-0.9$. The average annual precipitation is $350-400 \mathrm{~mm}$. The amount of temperature for the period of active vegetation is $3200-3500^{\circ} \mathrm{C}$. The rainfall during the period of active growing season is $250-300 \mathrm{~mm}$. Total number of days with hot dry winds is from 80 to 90 . Atmospheric drought occurs at a relative air humidity of 30\% or less. From 180-195 days of the warm period, average of 61 day falls on drought and hot winds. The winds from East, Northeast and Southeast also contribute to atmospheric drought. The soils of extremely arid zone are lightchestnut. The main limiting factor when cultivating agricultural crops in the concerned area is moisture. Adverse weather conditions (droughts, hot winds, and dust storms) were apparent in almost all the years of observation.

The research was carried out under the protection of permeable protective forest strips 1012 meters in width, reaching a height of 8-10 meters. Experiments were conducted in three replications. Due to the fact that the effect of protective forest strips on crops depends on the remoteness from the field to the forest strip, phenological observations and harvest accounting were carried out on plots (options), i.e. stints located at the following distances to the Northwest of the protective forest strip: 10-20H (Option 1), 20-30Í (option 2), and 30-40H (option 3). Record size of the plots was equal to $5 \mathrm{~m}$ in width and $50 \mathrm{~m}$ in length. A breakdown of the total plots was carried out after emergence of crops. The study was aimed at determining the effect of protective forest strips on available water supply, weediness and yield of agricultural crops.

\section{RESULTSAND DISCUSSION}

Ameliorative role of protective forest strips is manifested, primarily, through decreasing of wind speed and weakening of turbulent exchange, which have a significant impact on changing the microclimate elements on the forested field. Forest shelter belts, exerting a certain influence on the fields' ecology, affect thereby the growth and crop productivity that is the primary criterion for assessing ameliorative economic efficiency. The article presents the research outcomes concerning the role of protective forest strips in the formation of the winter wheat crop on the agricultural lands in the arid zone of the Central Fore-Caucasus. Studies have shown that the productive moisture content in the winter wheat cultivated on the lands protected by forest strips is greater than that under the unprotected field conditions. The amount of available moisture varied depending on the remoteness from the protective forest strip. Work practices in the dry steppe zone have a profound effect on the accumulation and preservation of moisture in the soil. Some researchers, when studying the effect of processing methods, aimed at maintaining moisture content of the soil, indicated that various treatment methods and amount of fertilizers have differently affected the accumulation of moisture in the soil [4.5.11]. It is proven that microbiological processes in woodlands are more active than those on the field without protective plantings. At that, soil microbiological activity in the winter wheat increases while getting closer to the protective forest strip. The studies revealed that protective forest strips in combination with soil-protective technologies boost yields of winter wheat by 10 $15 \%$. A favorable environment for soil microorganisms in terms of moisture is ensured at soil moisture ranged within $60-70 \%$ of the smallest moisture-holding capacity. The same interval provides physical mellowness of soil, i.e. its most favorable state for treatment. Water-logged soil is characterized by disturbed air conditions and accumulation of toxic products of aerobiosis. Lack of water in the soil deteriorates its agro-physical properties, suppresses biological and chemical processes that reduces the amount of available nutrients ${ }^{6}$. 
In the conditions of Central ForeCaucasus the winter wheat crop depends mainly on deposits of moisture in the soil, which are primarily determined by previous cropper, timing of harvesting, as well as tillage and irrigation conditions. Besides, protective forest strips, namely their remoteness from the field, have great importance for the formation of winter wheat? Remoteness from a protective forest strip has a significant effect on the accumulation of productive moisture by the time of sowing winter wheat. In this regard, we determined the content of productive moisture in the soil for all experimental plots. Snow accumulation plays an important role in the formation of soil moisture. Equalization of the snow distribution by shelterbelts has a beneficial effect on the yield of agricultural plants. Snow accumulation on the fields improves the temperature conditions of winter crops wintering, increases soil spring pre-irrigation, and reduces snowmelt runoff. Without protective forest strips fields are losing up to $50 \%$ of snow, demolished in the ravines and gullies. At the presence of protective forest strips, the snow blanket thickness on the fields increased on average by $20-40 \%$.

In our experiment, carried out in the conditions of the most snowy and windy winter, snow banks, turning into the snow trails, were formed up to $50 \mathrm{~cm}$ in height. The total length of the snow trail reached $100 \mathrm{~m}$ with a gradual decrease in snow layer thickness to $20-10 \mathrm{~cm}$. During the spring there was a massive snow deposition under the canopy of the protective forest strip. Maximum spring moisturization was noted at a distance of $0-10 \mathrm{H}$ to both sides of the windbreaks (Table 1).

Moisturizing effect of protective forest strips is particularly valuable in dry years, when additional moisture allows the plants to grow strong, to develop and form a strong root system ${ }^{8,}$ ${ }^{9}$. As shown in Table 1, snow cover height reduces with increasing the remoteness from the protective forest strip. Thus, at a distance of $10-20 \mathrm{H}$ snow cover depth was $25-30 \mathrm{~cm}$. With further increase in remoteness from the protective forest strip snow cover depth was decreased by $5-10 \mathrm{~cm}$. Total effective distance of protective forest strip ranged from 0 to $30^{\circ} \mathrm{C}$.

The soils close to the protective forest strips are moisten most of all. The beneficial effect of protective forest strips on soil moisture makes itself felt particularly in dry years. Moisture accumulated by protective forest strip has the greatest effect on plants in spring and early summer period, until plants did not consumed it completely. During this period, the plants growing on fields protected by forest strips, have time to form welldeveloped root system and better tolerate the lack

Table 1. Snow distribution depending on the remoteness from the protective forest strip, $\mathrm{cm}$

\begin{tabular}{lcccc}
\hline \multirow{2}{*}{$\begin{array}{l}\text { Period of } \\
\text { observations }\end{array}$} & \multicolumn{4}{c}{ Remoteness from the protective forest strip (H) } \\
\cline { 2 - 5 } & $0-10$ & $10-20$ & $20-30$ & $30-40$ \\
\hline January - February & $40-50$ & $25-30$ & $15-20$ & $15-20$ \\
\hline
\end{tabular}

Table 2. The influence of protective forest strips on productive moisture, mm

\begin{tabular}{|c|c|c|c|c|c|c|c|c|}
\hline \multirow[t]{2}{*}{ No } & \multirow{2}{*}{$\begin{array}{l}\text { Remoteness from the } \\
\text { protective forest }\end{array}$} & \multirow{2}{*}{$\begin{array}{l}\text { Soil } \\
\text { layer, } \\
\text { cm }\end{array}$} & \multicolumn{3}{|c|}{$2012-2013$} & \multicolumn{3}{|c|}{$2013-2014$} \\
\hline & & & $\begin{array}{c}\text { Fully } \\
\text { germinated } \\
\text { winter wheat }\end{array}$ & $\begin{array}{l}\text { Beginning } \\
\text { of booting }\end{array}$ & $\begin{array}{c}\text { Full } \\
\text { maturity }\end{array}$ & $\begin{array}{c}\text { Fully } \\
\text { germinated } \\
\text { winter wheat }\end{array}$ & $\begin{array}{l}\text { Beginning } \\
\text { of booting }\end{array}$ & $\begin{array}{l}\text { Full } \\
\text { maturity }\end{array}$ \\
\hline \multirow[t]{2}{*}{1.} & $10-20 \mathrm{H}$ & $0-20$ & 24.6 & 28.3 & 16.2 & 19.4 & 27.3 & 10.8 \\
\hline & & $0-100$ & 76.1 & 157.8 & 58.1 & 67.5 & 34.5 & 52.2 \\
\hline \multirow[t]{2}{*}{2.} & $20-30 \mathrm{H}$ & $0-20$ & 21.2 & 24.8 & 12.0 & 15.9 & 20.0 & 8.4 \\
\hline & & $0-100$ & 71.2 & 128.1 & 40.4 & 55.8 & 99.3 & 34.2 \\
\hline
\end{tabular}


of moisture in the soil in the second half of the growing season.

In the period of winter wheat booting, productive moisture reserves ranged depending on the remoteness from the protective forest strip from 28.3 to $157 \mathrm{~mm}$ (depending on soil layer) in 2013, and within the range of 27.3-34.5 mm during more arid year of 2014, while in 2014, less favorable in terms of climatic conditions, moisture supply during the booting was slightly lower, ranging from 27.3 to $34.5 \mathrm{~mm}$. However, the moisturizing effect of protective forest strip under arid conditions in 2014 has spread to a distance of $200 \mathrm{~m}$ from the forest strip. At the beginning of winter wheat booting, moisture content in various experimental options has increased because of winter-spring precipitation. The amount of moisture in the soil sharply decreases by the stage of full maturity, because by this time winter wheat consumes significant amounts of moisture from the soil, whereas, typically, this period is characterized by little rainfall as compared to the autumn-winter period. The decrease in moisture content was noted in proportion to the from the protective forest strip (Table 2).

The key factor in improving the growing conditions of crops planted among protective forest

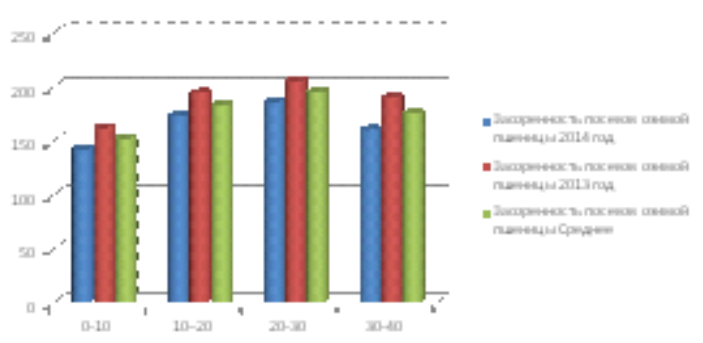

Fig. 1. Weed infestation of winter wheat crops depending on the distance to the protective forest strip (tillering stage)

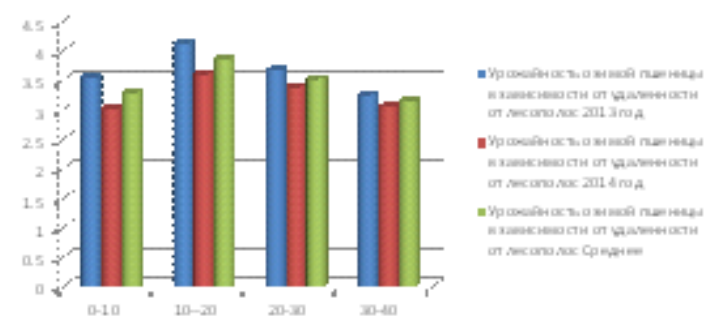

Fig. 2. The yield of winter wheat depending on the remoteness from a protective forest strip, $\mathrm{t} / \mathrm{ha}$ strips is a reduction in the evaporation ${ }^{10}$. The affected area of single protective forest strip on evaporation corresponds approximately to the area of their wind-sheltering effect. In our experiments the consumptive water use increased with the distance between the field and the protective forest strip. Thus, at a distance of $10 \mathrm{H}$ water-use ratio amounted to $756 \mathrm{~m}^{3} / \mathrm{ha}$, while at a distance of 20 30Í water-use ratio was equal to $891 \mathrm{i}^{3} /$ ha, i.e. the evaporating capacity of the plants increases with increasing remoteness from the forest strip, because the ameliorative effect of the protective forest strip reduces. The effect of reducing the evaporation strongly increases with the decrease in the size of the squares, formed by protective forest strips, because in the hard-to-irrigate areas with insufficient rainfall, the size of the squares should be reduced by two or three times as compared to the average sizes. This gives the opportunity to save on evaporation $40-100 \mathrm{~mm}$ of moisture that can significantly improve growing conditions of crops in these areas.

Studying the effect of protective forest strips on phytosanitary condition of winter wheat crops has shown that the species composition of weeds in the years of experimentation was represented by broad variety. At that, mainly dominated wintering plants and some species of perennial weeds ${ }^{11}$.

The following weeds were distributed in winter wheat crops: bagged sailor (Centaurea cyanusL.), wax dolls (Fymaria officinalisL.), goose grass (Galium aparineL.), caseweed (Capsella bursa - pastorisL.), corn buttercup (Ranunculus arvensisj.), convolvulus arvensis (bindweed arvensisL.), corn mayweed, wild chamomile (Matricaria inodoraL.), chorispora tenella (Chorispora tenellaPall, DC), ivy-chickweed (Veronica hederaefolia), and canada thistle or prickly thistle (Cirsium arvenseL.).

The availability of the protective forest strip had a definite effect on weed infestation of winter wheat crops (Fig.1).

During the winter wheat tillering stage, the lowest number of weeds was observed at a distance of $0-10 \mathrm{H}\left(152\right.$ plants per $\left.\mathrm{m}^{2}\right)$. Upon getting away from the protective forest strip the number of weeds increased, while at a distance of $30-40 \mathrm{H}$ from the protective forest strip the number of weeds decreased. Thus, at a distance of $30-40 \mathrm{H}$ from the 
field the number of weed plants was 175 plants per $\mathrm{m}^{2}$. Fairly high infestation at the tillering stage can be explained by the fact that winter wheat has not yet formed strong stalks, whereas the environment was favorable for weeds growth. Hydration near protective forest strips due to accumulated snow and spring moisture contributed to the high accumulation of weeds. In subsequent stages of the winter wheat growth, when the plant was already well developed and overshadowed the weeds, its competitive ability increased that led to reduction in number of weeds in all studied plots.

By the time of full ripeness of winter wheat, overwintering and early spring weed plants have finished their growing season, and the overall weediness of crops decreased. Just biennial, perennial, and isolated late spring and overwintering weeds, which formed a rosette of leaves in the spring, are vegetating at this time.

The reduction in winter wheat productivity is influenced not so much by the number of weeds, but their mass. The data obtained suggest that vegetative mass of weeds differed in terms of the development stages of cultivar and the remoteness from the protective forest strip. The highest mass of weeds at tillering stage was observed at a distance of 20-30í. At that, the mass of weeds increased in the booting stage $\left(164 \mathrm{~g} / \mathrm{m}^{2}\right)$.

By the time of full ripeness of winter wheat the mass of weeds decreased due to the end of the growing season and was almost equal on all studied plots (Fig. 2).

The main goal of conducted study was to increase crop productivity. The obtained data analysis in terms of crop productivity is the major outcome of the present research.

The beneficial effect of protective forest strips on the growing conditions of crops was manifested in the weakening of the wind speed and the intensity of turbulent exchange that contributed to the snow retention and reduced evaporation. Eventually, this led to an increase of soil moisture content and more effective consumption of moisture on evaporation and transpiration. This fact provided the increase in field yields in dry conditions. Soils under protective forest strips have the ability to accumulate surface runoff from fields that creates conditions for the successful growing of protective forest strips even at small precipitation. Accumulation of surface runoff by protective forest strips contributes also to increase of groundwater level and reduction of soil erosion due to flood waters and summer showers. The decreasing of wind speed reduces the probability of dust storms and droughts ${ }^{12,13}$.

The yield under favorable conditions of 2013 amounted to $3.65 \mathrm{t} / \mathrm{ha}$ and was higher as compared to less humid year of 2014 (3.26 t/ha). The effect of protective forest strips was manifested in a following way: the maximum yield (3.86 t/ha) was obtained at a distance of $10-20 \mathrm{H}$ from the protective forest strip (average for two years). At a higher remoteness yield decreased almost proportionally.

\section{CONCLUSION}

The formation of an artificial phytocenoses in agricultural-forest landscapes occurs under the direct influence of protective forest plantation. Describing the causes of the degradation, it is necessary to carry out comprehensive study of all the factors that affect these processes ${ }^{13}$. The affected area of the protective forest strips extends to a distance of 30$40 \mathrm{H}$. This impact is most fully manifested in the drier growing seasons. Changes are associated with structural morphometric and qualitative parameters of phytocenoses. Decrease in deposits of moisture was observed with increasing the remoteness from the protective forest strip. Favorable growing conditions for winter wheat were achieved within the area of $10-20 \mathrm{H}$. The deposits of moisture decreased depending on the cropper growth stage. During the tillering stage of winter wheat, the lowest number of weeds was observed at a distance of $0-10 \mathrm{H}$ (152 plants per $\mathrm{m}^{2}$ ). Their amount increased upon increasing the remoteness from the protective forest strip, and at a distance of 30$40 \mathrm{H}$ to the shelterbelt number of weeds was decreased. Maximum crop productivity ( $3.86 \mathrm{t} / \mathrm{ha}$ ) was obtained at remoteness from the protective forest strip equal to $10-20 \mathrm{H}$ (average for two years). At larger distances crop productivity decreased almost proportionally. Thus, optimal conditions for obtaining stable yields in the arid conditions of the Central Fore-Caucasus were reached in the options where the remoteness from the protective forest strip was $10-20 \mathrm{H}$. 
Deposits of productive moisture during the germination of seeds and the critical period were optimal. Despite the large amounts of accumulated snow, at the remoteness from the protective forest strip equal to $0-10 \mathrm{H}$, the lower yield of winter wheat (1.58 t/ha), compared to the above option, was due to the proliferation of weeds that increased the use of moisture and led to reduction in yields.

\section{ACKNOWLEDGEMENTS}

The authors express profound gratitude to Professor Vladimir I. Trukhachev, Rector of the Federal State Budgetary Educational Institution of Higher Professional Education Stavropol State Agrarian University, for the opportunity to conduct research at innovative accredited "Laboratory of Field Crops Cultivation Technology”.

\section{REFERENCES}

1. Pismennaja, E.V., Loshakov, A.V., Shevchenko, D.A., Odincov, S.V., Kipa, L.V., "Comprehensive Approach for Evaluating the Potential of the Stavropol Agricultural Territory,” International Journal of Economics and Financial 2015; 5(35): 113-120.

2. Vlasova, O.I., Perederieva, V.M., Volters, I.A., Tivikov, A.I., and Trubacheva, L.V., "Change in Microbiological Activity under the Effect of Biological Factors of Soil Fertility in the Central Fore-Caucasus Chernozems," Biology and Medicine, 2015; 7(5).

3. Bao, Y., Li, H., and Zhao, H., "Effect of Shelterbelts on Winter Wheat Yields in Sanded Farmland of North-Western Shandong Province," Journal of Food, Agriculture and Environment, 2012; 10(3-4): 1399-1403.

4. Esaulko, A.N., Salenko, E.A., Sigida, M.S., Korostylev, S.A., and Golosnoy, E.V. “Àgrochemical Principles of Targetting Winter
Wheat Yield on Leached Chernozem of the Stavropol Elevation,” Biosciences Biotechnology Research Asia, 2015; 12(1): 301-309.

5. Huang, G.-B., Guo, Q.-Y., Zhang, R.-Z., (...), Chan, K.Y., "Effects of Conservation Tillage on Soil Moisture and Crop Yield in a Phased Rotation System with Spring Wheat and Field Pea in Dryland,” Acta Ecologica Sinica, 2006; 26(4), pp. 1176-1185.

6. Lozinskaya, E.A., and Dzhogan, L.Ya., "Significance of Spatial Soil-Moisture Storage Variability for Estimating Heat and Moisture Exchange between the Atmosphere and the Underlying Surface,” Russian Meteorology and Hydrology, 1997; 6: 68-74.

7. Cleugh, H.A., Effects of Windbreaks on Airflow, Microclimates and Crop Yields," Agroforestry Systems, 1998; 41(1): 55-84.

8. Allen, R.G., Pereira, L.S., Raes, D., and Smith, M., "Crop Evapotranspiration: Guidelines for Computing Crop Water Requirements,” FAO Irrigation and Drainage Paper, 1998; 56.

9. Dong, Z., Ouyang, F., Lu, F., and Ge, F., "Shelterbelts in Agricultural Landscapes Enhance Ladybeetle Abundance in Spillover from Cropland to Adjacent Habitats," Bio Control, 2015; 60(3): 351-361.

10. Sheptukhov, Â.Í., "Changes in Hydraulic Properties of Subplow Horizons and in Soil Aeration-moisture Regime of Loamy SodPodzolic Soils due to Deep Loosening," Eurasian Soil Science, 1995; 27(2): 70-83.

11. Kort, J., "Benefits of Windbreaks to Field and Forage Crops,” Agriculture, Ecosystems and Environment, 1988; 23(Ñ), pp. 165-190.

12. Iturri, L.A., Avecilla, F., Hevia, G.G., and Buschiazzo, D.E., "Comparing Adjacent Cultivated and "Virgin” Soils in Wind Erosion Affected Environments can Lead to Errors in Measuring Soil Degradation,” Geoderma, 2016; 264: 42-53.

13. Ciecholewski, Ì., “An Edge-based Active Contour Model Using an Inflation/Deflation Force with a Damping Coefficient,” Expert Systems with Applications 2016; 44: 22-36. 